\title{
Lumen
}

Selected Proceedings from the Canadian Society for Eighteenth-Century Studies

\section{Reason and the French Revolution: Burke's Empiricism vs. Cartesian-style Deduction.}

\section{George C. McElroy}

Volume 15, 1996

URI : https://id.erudit.org/iderudit/1012476ar

DOI : https://doi.org/10.7202/1012476ar

Aller au sommaire du numéro

Éditeur(s)

Canadian Society for Eighteenth-Century Studies / Société canadienne d'étude du dix-huitième siècle

ISSN

1209-3696 (imprimé)

1927-8284 (numérique)

Découvrir la revue

Citer cet article

McElroy, G. C. (1996). Reason and the French Revolution: Burke's Empiricism vs. Cartesian-style Deduction. Lumen, 15, 97-114.

https://doi.org/10.7202/1012476ar d'utilisation que vous pouvez consulter en ligne. 


\section{Reason and the French Revolution: Burke's Empiricism vs. Cartesian-style Deduction.}

'No wonder these men shouted at each other,' said the late Prof. Ronald Crane when, at the end of his Burke course, he had brought us to see that Burke and Paine were not arguing with each other; they were arguing different questions. Paine argued about the rights of the French to do what they did and the desirable outcomes; Burke argued about the likely outcomes. This was not mere mis-understanding; it was the inescapable result of differences in the premises they started from and in the kinds of reasoning they used, and therefore in the kinds of questions they could try to answer. True, Burke, Paine, and the other writers who answered Burke's Reflections on the Revolution in France did all agree on two things: (1) Revolutionary France was something new and unprecedented, (2) the standard by which to judge it was reason. But Burke had one concept of reason; most of his critics a different one. Never the twain could meet; each side repeatedly denounced the other as irrational.

I want to look first at the reasoning of some of Burke's most notable British opponents; this seems backward, but they wasted many words refuting positions he did not hold (particularly, that the 1689-90 Revolution Settlement had bound future generations to put up with whatever aberrant monarchs they might thereafter endure, ${ }^{1}$ or that emotion and prejudice should replace reason), while their methods of reasoning were in many cases so like the French ones Burke was attacking, that it can be useful to see how such methods worked before looking at his attack.

First to denounce Burke's Reflections on the Revolution in France was Mary Wollstonecraft, in her Vindication of the Rights of Men: 'I glow with indignation when I attempt methodically to unravel your slavish paradoxes, in which I can find no fix'd first principle to refute.' He had, she perceived, 'a mortal antipathy to reason. ${ }^{2}$ Still glowing, she insisted that, as opposed to Burke's wit and imagination, 'the operations of judgment ... are cool and circumspect; and coolness and deliberation are great enemies to enthusiasm'(139). Her calm (if glowing) reason went to the ultimate source; all who pretend to rationality 'build their morality and religion on an everlasting foundation - the attributes of $\operatorname{God}^{\prime}(9)$. That 
is, 'I fear that sublime power, whose motive for creating me must have been wise and good; and I submit to the moral laws which my reason deduces from this view of my dependence on him.' She submitted, not to His power, nor to 'an arbitrary will, but to unerring reason'(78).

That reason told her that 'There are rights which men inherit at their birth, as rational creatures, who were raised above the brute creation by their improvable faculties, and ... in receiving these, not from their forefathers but from God, prescription can never undermine natural

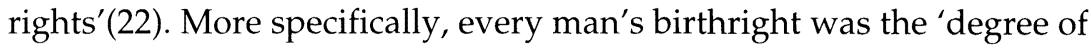
liberty, civil and religious, ... compatible with the liberty of every other individual with whom he is united in a social compact,' but everywhere 'the demon of property has ... been at hand to encroach on the sacred rights of men, and to fence round with awful pomp laws that war with justice' $(7-8)$. The only property-right sanctioned by nature and reason is every man's right to enjoy and bequeath what 'his talents and industry have acquired'(51). Hereditary property and honour change a man 'into an artificial monster by the station in which he was born' and benumb his faculties; else, having 'a capacity of reasoning' he would discover, 'as his faculties unfolded, that true happiness arose from the friendship and intimacy which can only be enjoyed by equals'(12).

This and other imperfections of modern governments largely arose from their having been constituted 'in the dark days of ignorance, when the minds of men were shocked by the grossest prejudice and most absurd superstition' - no models to cite reverently (18-19). Were Burke's 'servile reverence for antiquity, and prudent attention to self-interest to have the force which he insists on, the slave trade ought never to be abolished' (23-24). So she asks Burke, the champion of antiquity, continuity, prescription and property, to ask his heart, when he calls himself a friend of liberty, should it not rather be 'the champion of property, the adorer of the golden image which power has set up?'(20)

Reason, she reiterates, is improvable. But she expects little improvement from Burke; he has too much wit. 'Great quickness of comprehension and facile association of ideas, naturally preclude profundity of research'(139). Apparently, lack of wit had enabled her to do more cool research in two weeks than Burke had done in a year.

Catherine Macaulay praised coolness almost as heatedly and with more italics; finding Burke 'obliged to substitute a warm and passionate declamation to a cool investigation, and to address the passions instead of the reason,' she felt reassured that she was right in her own judgment and feelings about that 'interesting event,' the French Revolution. ${ }^{3}$ Though less systematically deductive than Wollstonecraft, she too sees government as based on simple principles established by philosophical reason. Burke, she says, seems to think statesmen should base the happiness of 
society on 'prejudice, opinion and the powers of the imagination.' But these, philosophers think, cause 'all that is vicious and foolish' in men, and thus their misery. Truth is the only basis of happiness, and every un-truthful opinion is a treacherous guide - the less truthful, the more dangerous (7).

Thus the French Revolution was the 'sudden spread of an enlightened spirit,' which barred those 'usurpations' which, from the 'beginning of social life the crafty have imposed on ignorance'(10), although she did not blame this on property, as did Wollstonecraft. With the old French commonwealth 'torn to pieces' by contending parties, the builders of the new structure saw no duty or reason to use old materials they thought injurious, nor did they understand how any opposition of interests could produce harmony; they chose 'a simple rule' for the new stucture, 'regulated with all that art and design which the experience of ages affords to the wisdom of man.' They think they have made the best use of experience, given that history is no guide, since representative government is a new invention (33) and never in history has 'any government in a large empire ... in the strictest sense of the word, ... secured to the citizen the full enjoyment of his rights'(36).

Macaulay's second husband had been a Scottish printer, and she was evidently sufficiently up on trans-Tweed intellectual developments to make frequent appeals to human nature. For example, once the French constitution is settled and working, the human 'disposition for preserving peace and order will regain its natural force'(17), despite the 'petulant observations' of men deprived of privileges by the new order in France - an excusable 'weakness almost inseparable from human frailty'(10). She agrees with Burke that succeeding Bourbon monarchs, unless illiterate, would be hostile to the new constitution: 'this is nature' - and is the reason to strictly limit royal power. And the excessive wealth of the Church 'tended, by the natural course of moral causes ... to corrupt rather than to encrease and invigorate those qualities of the mind, and those spiritual endowments, which are to be desired in the teachers of religion'(24).

This, as I explain below, would be meeting Burke on his own ground, except that few of these observations are central to her arguments. She admits (no doubt mindful of Adam Smith) that those unable to work are entitled to a maintenance by the 'laws of humanity,' because God has, for the best purposes, woven 'sympathy into the Constitution of all his moral creatures,' but she insists this does not mean they should all be able to vote. More politically pertinent is the converse observation that 'to act by selfish considerations, is in the very constitution of our nature'(20). It is this 'leaven of selfishness' which, she says, makes impracticable Burke's recommendation of a 'tardy caution which suffers the spirit of 
reform to evaporate before their work is half finished.' Instead, legislators must regulate every detail of a new constitution in the way they think best, since any defect supports a soon vested partial, not public interest, which defeats any attempt to correct that defect (30-31). (Burke's question could have been, 'but why expect reforming legislators to be so unselfish they need no restraint?')

But she is less concerned with any such details than with the simple general principles which, she believes, the French legislators grasped and which are all they needed. Thus, she says, Burke makes 'eternal war' against 'the simplicity of all abstract principles,' and thinks 'the devices of pride, ... fond conceits of vanity, ... the ... pompous ostentation' which subordinates 'naked virtue' to 'external magnificence' are useful to give dignity to ourselves. But only 'true dignity of character ... ought to constitute distinction'(22-23).

The French display it by firmly and unitedly supporting their rights, yet obeying the government they have appointed. Whence this difference from the 'barbarous ignorance' and 'depravity of character' in other European states? From 'a more general diffusion of knowledge and ... a principle of action which consults the public good as well as the gratifications of self.' She hopes it can 'prevail over that mist which inordinate affections cast over the mind,' and thus produce universal co-operation throughout France (10-11;36). Clarity, simplicity, suspension (somehow) of selfishness, and - above all - knowledge can, she happily asserts, solve political problems; human nature merely complicates them a bit.

James Mackintosh, in his Vindiciae Gallicae, the second-most effective answer to Burke, agreed that reforms should be quick and thorough-going, before the reforming impulse could die away: 'In a great Revolution, every expedient ought to facilitate change. In an established Government, every thing ought to render it difficult ... In a Revolution, the enemies of freedom are external, and all powers are therefore to be united. Under an establishment her enemies are internal, and power is therefore to be divided. ${ }^{4}$

Mackintosh is, if anything, more rigorously deductive than Wollstonecraft in demonstrating what those united powers were to establish, forthwith. For nearly a century, European philosophers had 'discussed all objects of public oeconomy,' reaching a degree of agreement and certainty perhaps as much as 'such topics will admit,' so that all the National Assembly needed to do was, not make discoveries but merely 'affix the stamp of laws to what had been prepared by the research of philosophy'(117-18). Geometry is to mechanics what abstract reasoning is to politics(119); more specifically, 'the rights and the nature of man are to the Legislator what the general properties of matter are to the mechanic' - the guide 'founded on the widest experience.' As a Scot, 
Mackintosh believed that 'metaphysics' (as psychology and epistemology were called in Scotland) had determined the nature and calculated the strength of men's passions and interests, the moral forces politicians work with, 'as mathematics do those of the mechanical powers'(113).

Thus all was ready for constructing a government of art, or intellect, 'on the immutable basis of natural right and general happiness,' combining the excellencies and excluding the defects of those 'fortuitous' governments which 'chance had scattered over the world,' and which could not be presumed to have 'surpassed the works of intellect, and precluded all nearer aproaches to perfection.' It was time 'that Legislators, instead of that narrow and dastardly coasting which never ventures to lose sight of usage and precedent, should, guided by the polarity of reason, hazard a bolder navigation, and discover, in unexplored regions, the treasure of public felicity.' A new magnetic compass of politics was ready to guide that political Columbus, the National Assembly, beyond sight of old political coast-lines: it was the press, a new force, which had 'subjected the powerful to the wise, by governing the opinions of mankind' (115-117).

Unlike Macaulay, he does clear Burke of holding 'that possession legitimates tyranny, or that fact ought to be confounded with right.' $\mathrm{He}$ says, correctly, that Burke only argues that the 'illusion' of antiquity 'endears and ennobles freedom ... by rendering it august and venerable in the popular mind.' But 'to the friends of freedom' the 'expediency of political imposture' is 'a principle odious and suspected ... as the grand bulwark of secular and spiritual despotism,' and a libel on human understanding. Primary political truths are few and simple. It is easy to make them understood, and to transfer to Government 'the same enlightened self-interest that presides in the other concerns of life' (306-307).

Thus, the National Assembly was called on to make a clean sweep of old institutions, including the 'corporations' of Nobility, Church, and Parliaments, on the one general principle 'adopted by the French Legislators - that the existence of Orders is repugnant to the principles of the social union'(67). Like Wollstonecraft (and like Paine, subsequently), he looks to origins; they are enough to make such 'orders' 'unfit to be members of a free government ... their corporate character had been formed under arbitrary establishments' and they had 'imbibed every sentiment, and adopted every habit under arbitrary power'(70-71).

Exemplifying Mackintosh's new political geometry is his argument for universal suffrage as a natural right. A man resigns any of his 'natural sovereignty over his own actions' only to be protected from other men's abuse of that same dominion. Consequently, he need sacrifice no more than this requires - powers which might hurt others. He therefore 
retains a right to share in his own government, because one man's having that right is not inconsistent with other men's having it too, which is the only case in which society can exact the surrender of a natural right(207210). And the slightest deviation from this rule would legitimate every tyranny (217-219). QED.

Indeed, though all morality and justice are 'founded on a broad and general expediency,' it is expediency by general maxims 'into which reason has concentrated the experience of mankind.' But once a maxim is adopted, it must be obeyed even when not expedient; there would be no morality if everyone might judge, in each case, what was expedient, rather than what was right. This includes political first principles, such as the 'Rights of Man': 'These precise and inflexible principles, which yield neither to the seductions of passion, nor the suggestion of interest, ought to be the guide of Public as well as private morals.' For if expediency is considered, who will judge of it? The many cannot, while the few are interested in 'the perpetuation of oppression and abuse,' for 'there never was, or will be, in civilized society, but two grand interests, that of the RICH and that of the POOR.' Consequently, 'the moment that the slenderest infraction of these rights is permitted for motives of convenience, the bulwark of all upright politics is lost' $(217-219 ; 268)^{5}$ It sounds like a cross between Rousseau and Calvinism.

Indeed, while Rousseau dominates the dismissal of proposals for a second house of the legislature - there is only one general will and so no need to pronounce it twice (262-263) - the self-righteous Scottish urge to convert the heathen comes out in Mackintosh's conclusion: 'when philosophers become legislators, they are colonists from an enlightened country reforming the institutions of rude tribes'(365).

The self-educated Tom Paine, equally a missionary of that Reason which was to bring Europeans from the savagery of governments and social structures founded in the dark ages, into the light of the Rights of Man, was far the most popular of Burke's assailants. His style was clear, hard-hitting and direct, scoring sarcastic bull's-eyes on society's and governments' obvious absurdities and injustices. He had been the great propagandist of the American Revolution, and his hopeful predictions then seemed justified by the just-established new American constitution. Even more to the point, he, unlike the other apologists for the French Revolution, incessantly and persuasively connected old regime evils with their most direct effect on ordinary men: excessive taxation, the wars made, he repeatedly charged, as pretexts to increase taxes, and consequent wide-spread poverty in lands potentially rich enough for all. ${ }^{6}$ The money went for ridiculously exorbitant payments to courts and monarchs (look what America got for its money with Washington even had he accepted a salary - compared to what Europeans paid for 
imbecile rulers) (Rights, Part 2, 426) and, in England's boasted mixed government, for corruption of the Commons, since even England's imperfect elections let in enough reason it had to be bought off (1.380). 'To say that any people are not fit for freedom, is to make poverty their choice, and to say they had rather be loaded with taxes than not'(2.393).

Paine was even more dismissive than Wollstonecraft of Burke's abilities in political reasoning, and thought his language merely muddled, not wit. Burke's defence of the old system had, Paine thought, 'no point at all'(1.286). Had Burke possessed the talents of an Adam Smith, he would have comprehended all that goes into making a constitution, and reasoned from minutiae to magnitude (313); he would have discussed the revolution's origin and progress, not given consequences without their causes (297). He would have seen that the revolution was not against Louis XVI, but against the principle of the regime (284). He would not have made assertions without either evidence or argument (302). But Burke's prejudices and the 'disorderly cast of his genius' - a genius 'without constitution ... a genius at random and not a genius constituted'(313) - disqualified him and his like for such a subject, which 'takes in a field too vast for their views to explore, and proceeds with a mightiness of reason they cannot keep pace with' (284). Burke's book is 'all miscellany ... a mob of ideas tumbling over and destroying one another' (355). For, whereas 'before anything can be reasoned upon to a conclusion, certain facts, principles, or data to reason from, must be established, admitted, or denied' (302), Burke lacked any 'polar truth or principle,' the guide needed by anyone dealing with a 'long cause' if he is to keep the parts of his argument together 'and make them unite in one issue'(355) - that is, for Paine, the compass Mackintosh believed the French had found for Government serves also as a guide to composition.

Paine's own guided voyage started near Wollstonecraft's - with Creation, when man was one, and consequently all men equal in rights, which passed on to all subsequent generations (302-305). These include each man's right to act for his own comfort and happiness, when not injuring the rights of others, and, as a member of civil society, to enjoy those rights for which his own power is inadequate: security and protection. This leaves him every right he does have power to execute, such as intellectual rights, including religious belief; conversely, he loses the right to judge in his own cause, because he does not have power to execute that judgment (305-307). Thus civil power is merely the aggregate of those rights for which individual power is defective, and cannot invade any right individuals can execute.

Governments originate either over the people - whether by superstition (a government of priestcraft), or by power (a government of conquest)(307) - or from the people, when the nation, by a specially chosen 
convention, sets up a constitution to which the government must be subject and which the government cannot, of itself, alter: 'the right of reform is in the nation in its original character' - constitutionally, by a new, specially elected, convention (310-311). This is a government of reason; the others are governments of ignorance, and doomed once men are enlightened; nothing can make men un-learn what they know (35758).

England's government arose from the Norman Conquest, and has never been regenerated. Paine proves by definition it has no constitution: a constitution is an actual document, set up antecedent to government by the people acting as a whole, prescribing the basic elements, powers, and limitations by which the government is to operate. Can anyone show him the English constitution? (309) Monarchy,too, is easily dismissed, with one of Paine's favorite either/or arguments: if monarchy is useless, 'why is it kept up any where? and if a necessary thing, how can it be dispensed with?' (365)

All these controversialists' appeals to presumed first principles show that their concept of reason, like that of most French thinkers, belonged in what can loosely be called the Cartesian mode, one professedly modelled on mathematics: deducing, from one or a very few established premises, clear-cut 'rational' conclusions that could be applied, simply and definitively, to questions of government. It led such thinkers as Rousseau and d'Holbach to suppose that what government should be is an essentially simple question, requiring few compromises.

To them, that is what 'reason' meant. The Revolution's early supporters on both sides of the channel presumed that men, being reasonable, would recognize that a rational regime had been established, and therefore would readily support and obey it.

As Burke repeatedly protested, 'One would think such a thing as a medium had never been heard of in the moral world. ${ }^{7}$ As I have argued previously, Burke is intellectually a Scottish enlightenment empiricist that is, he reasons in terms of cause and effect, finding the most basic causes of moral developments, including government and social structure, in human nature (including both universal traits and the various 'second natures' produced by differing customs and experiences), plus the variables introduced by all sorts of 'circumstances'(Appeal 206-207). ${ }^{8}$ Burke adds a seasoning of Aristotle, whom he, long since, had cited for distinguishing between mathematics, which requires rigid demonstration, and ethics and politics, in which propositions can only be for the most part true and who found, as did Burke, that virtue lies in a rational, not mathematical medium between extremes.

Thus Burke had protested against a 'species of delusive geometrical accuracy in moral arguments as the most fallacious of all sophistry.' 'Far 
from a resemblance to those propositions in geometry and metaphysics which admit no medium, but must be true or false in all their latitude, social and civil freedom, like all other things in common life, are variously mixed and modified, enjoyed in very different degrees, and shaped into an infinite diversity of forms, according to the temper and circumstances of every community. The extreme of liberty (which is its abstract perfection, but its real fault) obtains nowhere, nor ought to obtain anywhere; because extremes, as we all know, in every point which relates either to our duties or satisfaction in life, are destructive both to virtue and enjoyment. Liberty, too, must be limited in order to be possessed. ${ }^{\prime 10}$

More basically, "The lines of morality are not like the ideal lines of mathematics. They are broad and deep as well as long. They admit of exceptions; they demand modifications. These exceptions and modifications are not made by the process of logic, but by the rules of prudence ... the first in rank of the virtues political and moral, ... the director, the regulator, the standard of them all. Metaphysics cannot live without definition; but Prudence is cautious how she defines'(Appeal 80-81). Consequently, while the excellence of mathematics and metaphysics is, to have but one thing before you; ... he forms the best judgment in all moral disquisitions who has the greatest number and variety of considerations in one view before him and can take them in with the best possible consideration of the middle results of all'(Works 7:73). But the experience of a whole lifetime is not enough to give anyone command of all the considerations pertinent to such a complex matter as government (Reflections, Oxford Edition, 8:112). That is why 'All government, indeed every human benefit and enjoyment, every virtue and every prudent act, is founded on compromise and barter. We balance inconveniences; we give and take; we remit some rights that we may enjoy others; and we choose rather to be happy citizens than subtle disputants'(Conciliation 169).

But the actors and apologists of the French Revolution, he said, chose otherwise. 'The pretended rights of these theorists are all extremes; and in proportion as they are metaphysically true, they are morally and politically false. The rights of men are in a sort of middle, incapable of definition, but not impossible to be discerned. The rights of men in governments are their advantages; and these are often in balances between differences of good; in compromises sometimes between good and evil, and sometimes, between evil and evil. Political reason is a computing principle; adding, subtracting, multiplying, and dividing, morally and not metaphysically or mathematically, true moral denominations'(Reflections 112-113). 
The uncompromising Paine epitomizes the gulf between his and Burke's modes of reasoning by quoting the last two sentences, and, presuming the 'wondering audience whom Mr. Burke supposes himself talking to may not understand all this learned jargon,' professes to interpret: 'government is governed by no principle whatever; ... it can make evil good, or good evil, just as it pleases. In short, ... government is arbitrary power'(Rights 1.356).

That is, Paine thought reason could clearly prove, once for all, what government should and should not do; consequently, compromise is unreasonable and arbitrary. Burke had no such faith in human reason's conclusiveness, though he ardently believed he was doing his best to make prevail what reason we do have. He incessantly complained that the French measures were irrational, and the leaders impervious to reason, whereas anyone with any political power should be morally limited by subjecting his 'occasional will to permanent reason, and to the steady maxims of faith, justice, and fixed fundamental policy'(Reflections 71). For anyone, it is safer 'to live under the jurisdiction of severe but steady reason than under the empire of indulgent but capricious passions' (Appeal 63), while the revolutionists were liable to exile from 'this world of reason, and order, and peace, and virtue'(Reflections 147). A basic raison d'être of the state is that 'man is by nature reasonable; and he is never perfectly in his natural state, but when he is placed where reason may be best cultivated and most predominates. Art is man's nature'(Appeal 176). But by 'reason' or 'rational' Burke, as an empiricist, always meant the choice of an action, policy, or institution which, logical or not, had at least a good chance of producing a desirable effect; what did not was not reasonable, however logical. And, long before, reason had told Burke not to rely too much on reason: 'Politics ought to be adjusted, not to human reasoning, but to human nature, of which reason is but a part, and by no means the greatest part. ${ }^{\prime 1}$ The English, says Burke, appeal to tradition and precedent because they 'are afraid to put men to live and trade each on his own private stock of reason; because we suspect that this stock in each man is small, and that the individuals would be better to avail themselves of the general bank and capital of nations'(Reflections 138). England's forefathers 'in their most decided conduct ... acted under a strong impression of the ignorance and fallibility of mankind. He that made them thus fallible rewarded them for having in their conduct attended to their nature' (292-93).

But the revolutionaries and their apologists had not. "This sort of people are so taken up with their theories about the rights of man that they have totally forgot his nature. Without opening one new avenue to the understanding, they have succeeded in stopping up those that lead 
to the heart. They have perverted in themselves, and in those that attend to them, all the well-placed sympathies of the human heart'(115).

Burke asserted that in Reflections he had, on the contrary, laid the foundations of Government, 'not in imaginary rights of men, (which at best is a confusion of judicial with civil principles,) but in political convenience and in human nature, - either as that nature is universal, or as it is modified by local habits and social aptitudes.' And though he admitted he did not 'know France as correctly as some others,' he had 'endeavoured through my whole life to make myself acquainted with human nature; otherwise I should be unfit to take even my humble rank in the service of mankind' - and he had, of course tried to include France, England's influential neighbour, in those studies (185).

They could not lead to the sort of clear-cut basic premise Burke's critics complained of not finding, let alone to their hoped-for simple solutions to political problems. 'The nature of man is intricate; the objects of society are of the greatest possible complexity; and therefore no simple disposition or direction of power can be suitable either to man's nature or to the quality of his affairs. When I hear the simplicity of a contrivance aimed at and boasted of in any new political constitutions, I am at no loss to decide that the artificers are grossly ignorant of their trade, or totally negligent of their duty'(112).

But knowledge of human nature did provide useful guide-lines. What lies in that larger, non-rational portion? Imagination and passions, to begin with, and as Burke had long before observed, where they are concerned 'reason is little consulted' ${ }^{\text {'2 }}$ - as true in politics as in aesthetics, but more dangerous. Imagination can beget the evil most terrifying to wisdom: epidemical political fanaticism (Reflections 202). 'There is a boundary to men's passions, when they act from feeling [i.e. from grievances actually felt]; none when they are under the influence of imagination.' That is, when a felt grievance is remedied, passions subside. But reforms only exacerbate a faction which, 'proceeding on speculative grounds, is thoroughly heated against its [government's] form'; improvements are despised as a plea for preserving instead of destroying it (Appeal 192).

Passions, such as pride, ambition, avarice, revenge, lust, ungoverned zeal, and 'disorderly appetites' may make some 'specious appearance of real good' a cover for persecution and riot (189-90). Avarice, ambition, love of power, love of glory can be dangerous if not properly directed and checked; useful if they are. Most ominously, love of adventure and excitement - even danger - can be stronger than the pleasures of a peaceful, industrious, but not well-rewarded life, a contrast that, as I have said, goes back to Burke's Sublime and Beautiful. 
But men also have affections and sympathies (Burke had been enthusiastic about Smith's Theory of Moral Sentiments), a 'strong struggle' to keep whatever a man 'has found to belong to him and to distinguish him' (Reflections 187) and innate moral sentiments (as nearly all the leading Scottish thinkers believed), 'so nearly connected with early prejudices as to be almost one and the same thing' (Appeal 205). The feelings they produce can correct shallow theories (Appeal 79); that is why Burke constantly reproaches the French law-makers with being 'cold-hearted.' These feelings and sentiments make for stability and civilization.

Those early prejudices, in particular, Burke argued, often prove to have their 'reasons' - that is, their usefulness, whatever their origins or lack of logic. And a prejudice with its reason is more useful than reason alone: it 'has a motive to give action to that reason, and an affection which will give it permanence. Prejudice is of ready application in the emergency; ... it does not leave the man hesitating in the moment of decision'(Reflections 138). (Implictly, Burke is agreeing with Hume that reason, alone, produces no action, and therefore is, and ought to be, the slave of the passions.) So Burke discovers the reasons for many European and English prejudices - oxymorons, to his rationalist critics.

For instance, the chivalric code was a cheap guarantee of fealty, decency, and respect for women, at least those of rank (127). The established church's easy pomp and high status for Bishops not only gave a sense of religious obligation to those in power, but ensured respect for religion (142-53) (this laid Burke open to George Rous's observation that Scotland managed to be as moral as England with no help from bishops, ${ }_{13}^{13}$ while Joseph Priestley pointed out that unpretentious dissenting and Methodist churches were filled and proliferating). ${ }^{14}$ France's monastic system, though not something one would have wished to initiate, was now filled with well-meaning men, working cheaply; surely it could have been put to constructive use (Reflections 207). And natural elites aristocratic, military, commercial, religious - all had training and experiences that helped fit them to lead (Appeal 174-75). Hereditary monarchy was, in English experience, the only safeguard of English liberty (shades of Cromwell)(Reflections 75), and a hereditary government 'had the image of a relation in blood,' procuring for government and the liberties it ensured the affections all have for their families (84-85).

This, said Burke, is the way those prejudices and the whole working of the British system is understood by 'not the least learned and reflecting part of this kingdom,' reasoning on grounds they comprehend. And those who can't follow such reasoning receive their opinions 'from an authority which those whom Providence dooms to live on trust need not be ashamed to rely on' (147-48). 
What the learned and reflecting understood, Burke contended, was that the British system balanced potentially conflicting interests and powers so that no one person or body had un-checked power; discussion and compromise were always necessary, and the opinions of many people contributed to all important decisions, yet there was seldom stalemate; decisions did get made and acted on. Sometimes the result could be a serious grievance to some people, but they could make their complaints heard, and usually secure some amelioration before too long. Consequently the people, predisposed by their prejudices and affections, on the whole peacefully obeyed and supported the government, so that violent exertions of authority were seldom needed, tyranny was unthinkable, liberty was reconciled with order, and the system was constantly, if carefully, improving (Appeal 212-13).

But the new French system had, and could have, no correctives at all (Appeal 106), and with a 'people whose character knows no medium ${ }^{15}$ it had abolished all the useful prejudices that support government. But 'that sort of reason which banishes the affections is incapable of filling their place. These public affections combined with manners, are required sometimes as supplements, sometimes as correctives, always as aids to law' ('Army Estimates' 129). Yet now (aside from any individual interests) 'laws are to be supported only by their own terrors ... In the groves of their academy, at the end of every visto, you see nothing but the gallows' (Reflections 128). Similarly, the Assembly, having 'destroyed all the opinions and prejudices, and, as far as in you lay, all the instincts which support government' must use the army to settle any differences between it and any recalcitrant part of the nation (268).

Differences, Burke perspicaciously supposed, were almost inevitable. For one thing, the precarious financial manipulations and inflation bound to follow the confiscation and sale of church lands to (inadequately) back the new paper 'assignats' would mean a shift of power, bound to be resented, from landholders and yeomen, unskilled in money matters, to the towns, 'among the burghers, and the monied directors who lead them'(241) - a shrewd forecast of Marx's 'bourgeois revolution.' In this, as in all measures, the National Assembly had 'every possible power and no possible external control,' nor any established laws, maxims, or rules of procedure; nothing could keep it 'firm to any system whatsoever'(Appeal 245).

Already, shocking devastations in France showed the effects of 'inconsiderate and presumptuous, because unresisted and irresistible authority' (Reflections 90) - the consequence of preferring, when the Estates General was turned into a National Assembly, 'a despotic democracy to a government of reciprocal control'(184). And 'perfect democracy,' Burke thought, is 'the most shameless thing in the world,' and 
the most fearless, since nobody, among so many, expects to be blamed or punished for what it does (144).

Once the Assembly unjustly seized the Church's property, other injustices (as well as an attack on Christianity) would follow: 'Criminal means once tolerated are soon preferred' as 'a shorter cut to the object than through the highway of the moral virtues' - and while public benefit would be the original justification, it would become the pretext for 'perfidy and murder ... until rapacity, malice, revenge, and fear more dreadful than revenge, could satiate their insatiable appetites'(132-33). In any hands, power, unsupported by manners and opinions, will anticipate 'plots and assassinations ... by preventive murder and preventive confiscation'(129). In this dangerously irresistible legislature, the sole qualifications for a legislator are 'an unfeeling heart and and undoubted confidence'(215). The succeeding Legislative Assembly will be even worse; the present one, by altering everything, will apparently have left them nothing to do; 'They will be roused by emulation and example to enterprises the boldest and the most absurd'(245). Under pressure from the Paris mobs, leaders will be bidders for popularity, and become

flatterers instead of legislators; the instruments, not the guides of the people. If any of them should happen to propose a scheme of liberty, soberly limited, and defined with proper qualifications, he will be immediately outbid by his competitors, who will produce something more splendidly popular. Suspicions will be raised of his fidelity to his cause. Moderation will be stigmatized as the virtue of cowards; and compromise as the prudence of traitors; until, in hopes of preserving the credit which may enable him to temper and moderate on some occasions, the popular leader is obliged to become active in propagating doctrines, and establishing powers, that will afterwards defeat any sober purpose at which he ultimately might have aimed (291).

Even Burke did not foresee the guillotine as the ultima ratio of regicides, but he did warn that if the new supreme tribunal was to be sworn to obey all rules, orders, and instructions the Assembly sent them, no gound of law would be left to the subject - the tribunals would be 'the most dangerous instruments in the hands of the governing power, which, in the midst of a cause, or on the prospect of it, may wholly change the rule of decision'(255). Danton would be able to agree, too late.

This Commonwealth 'can hardly remain' in its present state, 'but before its final settlement it may be obliged to pass, as one of our poets says, "through great varieties of untried being," and in all its transmigrations to be purified by fire and blood'(293). Meantime the officers of that army on which the Assembly must depend 'must totally lose the character of military men' if they obey transient successions of un-mili- 
tary 'pleaders' (eight of the fearsome 12-man Committee of Public Safety would be lawyers) 'with perfect submission and due admiration.'

For a time, the army will be

mutinous and full of faction, until [more shades of Cromwell] some popular general, who understands the art of conciliating the soldiery, and who possesses the true spirit of command, shall draw the eyes of all men upon himself. Armies will obey him on his personal account ... But the moment in which that event shall happen, the person who really commands the army is your master; the master (that is little) of your king, the master of your assembly, the master of your whole republic (266).

Though some other Burke predictions were wrong, this basic forecast is a depressingly accurate contrast to Paine's cheerful vision, in the last part of Rights, Part II, of all European monarchies being soon replaced by representative democracies, with a liberal league of America, France, and reformed England pressing Spain to free its American colonies and all powers to reduce their expensive, useless navies - since wars would cease once the people who pay for them were in control, while overseas dominions would be recognized as economically unrewarding. There might be some kind of European union. The peace dividend, plus savings on rulers (none, thought Paine, could be honestly worth more than $£ 10,000$ a year, though he was willing to concede, for England, that other officials might, if they wished, tax their own salaries to bring the ruler's stipend up to $£ 20.000$ ) to be used for a frugal welfare state - infant allowances, schools, old age pensions, jobs and training for poor city boys, etc.

It is an astonishingly pertinent program for the end of the 20th Century, with France in its 5th Republic (interspersed among two monarchies and two empires). It is that 'intuitive glance' to catch his 'ultimate object' which Burke conceded should be allowed to a reforming legislator's temperament, though 'his movements towards it ought to be deliberate' (217). But, as Burke said, the inferences from the soon-learned 'catechism of the Rights of Man' were 'in the passions. ${ }^{16}$ To the French revolutionists and their supporters, the prospects were too exciting for them to attend to Burke's kind of reason, however rational they thought themselves. But so long as men have limited reason and dangerous passions, if reforms are to come in less than two centuries, Burke and human nature might be the more rational guides.

\section{GEORGE C. MCELROY}

Chicago 


\section{Notes}

1 To counter Dr. Price's contention that the Glorious Revolution had given the English new rights to choose their monarchs and 'cashier them for misconduct,' Burke had insisted that the makers of that revolution had, on the contrary, done everything they could to minimize the novelty of what they were doing, including swearing an oath of fealty to the new monarchs and their heirs, for themselves and their posterity forever, copied from a similar oath made to Queen Elizabeth. As Priestley shrewdly pointed out, such an oath, made just when they were fracturing the old one, could hardly be more rigorously binding than that had been. Burke's point was simply that the Revolution settlement did not add new rights, though of course it did not take away the old fundamental one to act, in such a real emergency, in whatever way was necessary. And Burke repeatedly, though in very discreet ways, indicates that of course another such necessity would beget its own solution. But he did not want to raise questions about just when or how revolution might be justified; he did not think it possible to define the unforeseeable, and such discussions could only unsettle people at a time when no such necessity was even imaginable, while very radical reform schemes were very much in evidence.

2 Mary Wollstonecraft, A Vindication of the Rights of Men, in a Letter to the Right Honourable Edmund Burke; Occasioned by his Reflections on the Revolution in France, 2nd Edition (London: J. Johnson, 1790), 9.

3 Catherine Macaulay, Observations on the Reflections of the Right Hon. Edmund Burke, on the Revolution in France, in a Letter to the Right Hon. Earl of Stanhope (Boston: I. Thomas and E. T. Andrews. 1791), 3-4.

4 James Mackintosh, Vindiciae Gallicae. Defence of the French Revolution and its English Admirers, Against the Accusations by the Right Hon. Edmund Burke, Including Some Strictures on the Late Production of Mons. de Calonne (London: G. G. J. and J. Robinson, 1791) $\left(8^{0} ;\right.$ there was a quarto edition the same year), 42.

5 He adds, 'The differences of interest among the several classes of the rich [landed, commercial, ecclesiastic] will ever be too slender to preclude their conspiracy against mankind. In the mean time, the privileges of their several ORDERS will be guarded, and Mr. Burke will decide that GENERAL LIBERTY is secure!' This comes close to endorsing Wollstonecraft's charge that it is property particularly, inherited wealth - that is the great obstacle to the rule of Reason, though he never puts it in those terms.

6 E.g., inter multa alia, The 'revolutionary' change in French and English attitudes to each other (who could, a few years earlier, have foreseen or believed 'that a French National Assembly would ever have been a popular toast in England, or that a friendly alliance of the two nations should become the wish of either?') shows, Paine insisted, that man, uncorrupted by governments, 'is naturally the friend of man, and that human nature is not of itself vicious. That spirit of jealousy and ferocity, which the governments of the two countries inspired, and which they rendered subservient to the purpose of taxation, is now yielding to the dictates of reason, interest, and humanity.' Tom Paine, The Rights of Man, in Reflections on the French Revolution and The Rights of Man (Garden City, New York: Anchor Press/Doubleday, 1973) Part II, 444-5. Unfortunately, it took a while to follow that dictation. 
7 Edmund Burke, An Appeal from the New to the Old Whigs, in Consequence of some Late Discussions in Parliament Relative to the Reflections on the French Revolution (1791, 2nd edition), in The Works of the Right Honorable Edmund Burke, 9th Edition (Boston: Little, Brown, 1889) IV, 105. Citations from this edition refer hereafter to Works. The relevant volumes of the new Oxford Edition are cited where applicable.

8 George McElroy, 'Edmund Burke and the Scottish Enlightenment,' in Man and Nature/L'Homme et la Nature 11 (1992): 171-185.

9 'Man acts from adequate motives relative to his interest, and not on metaphysical speculation. Aristotle, the great master of reasoning, cautions us, and with great weight and propriety, against this species of delusive geometrical accuracy in moral arguments, as the most fallacious of all sophistry.' Edmund Burke, Speech on Moving His Resolutions for Conciliation with the Colonies. March 22, 1775 (hereafter, Conciliation). Works II, 170. Burke is alluding to the first book of the Nicomachean Ethics: 'precision is not to be sought for alike in all discussions, any more than in all the products of the crafts. Now fine and just actions, which political science investigates, admit of much variety and fluctuation of opinion ... We must be content then, in speaking of such subjects, and with such premisses to indicate the truth roughly and in outline, and in speaking about things which are only for the most part true, and with premisses of the same kind to reach conclusions that are no better ... for it is the mark of an educated man to look for precision in each class of things just so far as the nature of the subject admits; it is evidently equally foolish to accept probable reasoning from a mathematician and to demand from a rhetorician scientific proofs.' 1094b 12-16; 19-28. Tr. W. D. Ross, in The Basic Works of Aristotle, ed. Richard McKeon (New York: Random House, 1941) 936.

10 A Letter from Edmund Burke, Esqu; One of the Representatives in Parliament for the City of Bristol, to John Farr, and John Harris, Esqurs. Sheriffs of that City on the Affairs of America. Works II:229.

11 Observations on a Late State of the Nation, Oxford Edition, 2:196. This pamphlet is a collaboration between the Burkes and William Dowdeswell, who had been Chancellor of the Exchequer under the Rockingham administration, and was the party's floor leader in the Commons. Burke may have been visiting Dowdeswell when the Grenvillite State arrived; anyhow, Dowdeswell wrote a scathing dissection of Grenvillian economics (and arithmetic!); Burke wrote an introduction and a long addition, William and Richard Burke each contributing a couple of pages. This quotation is in Edmund's portion.

12 'On Taste,' in A Philosophical Inquiry into the Origin of our Ideas of the Sublime and Beautiful, ed. J.T. Boulton (London: Routledge, 1958) 26-27.

13 George Rous, Thoughts on Government: Occasioned by Mr. Burke's Reflections \&c. In a Letter to a Friend (London: Debrett, 1790) 15.

14 Joseph Priestley, Letters to the Right Honourable Edmund Burke, Occasioned by his Reflections on the Revolution in France (Birmingham: Printed by Th. Pearson, and sold by J. Johnson, London, 1791.) In this series of letters Priestley takes a much less dogmatic view of the French Revolution than do most of Burke's critics. He admits that when people have revolted against some grievance, they at first concentrate too much on destroying it, not enough on what is to be put in its place. But he presumes that, like the Americans, they will, by trial and error, improve their new government until it does what they want. Most of Priestley's 


\section{George C. McElroy}

'Letters' concentrate more on defending the dissenting churches, as much more effective than was the established Church in bringing religion to the general public; he also points out that, whereas Burke had warned that the French provision for having curates elected would engage applicants in demeaning electioneering, Congregational churches in England regularly elected their ministers with no such unseemly practices. Priestly's position was the most moderate among apologists for the Revolution; it made him the most trouble.

15 Substance of the Speech in the Debates on the Army Estimates in the House of Commons, On Tuesday, February 9, 1790: Comprehending A Discusssion of the Present Situation of Affairs in France. Works III: 217-18. This account is a collaboration; Richard Burke sr. wrote the first 11 paragraphs, except that the second was inserted by someone, perhaps French Laurence; Edmund wrote the next 16 paragraphs, and his son, Richard jr. finished the account. The two Richards may well have been using Edmund's notes. The phrase quoted is in Edmund's portion.

16 Thoughts on French Affairs, \&c. \&c. Written in December 1791. Oxford Edition, $8: 359$. 